\title{
Burnout among nurses
}

\section{Wypalenie zawodowe u pielęgniarek}

\author{
Aneta Grochowska, Barbara Kubik, Urszula Romanowska, Monika Lebica \\ Department of Nursing, Institute of Health Protection, The State Higher Vocational School, Tarnów, Poland \\ Head of Department: Monika Łabuzek
}

Key words: burnout, satisfaction, health occupations.

Słowa kluczowe: wypalenie zawodowe, satysfakcja, zawody medyczne.

\begin{abstract}
Introduction: The process of occupational burnout develops slowly; its initial symptoms are discreet, they increase progressively and become manifest suddenly, with great power. The burnout syndrome constitutes a serious personal and social problem whose cause lies in the workplace or is work-related.

Aim of the research: To assess occupational burnout of nurses and the sense of satisfaction with career.

Material and methods: The study covered 100 nurses working for the Health Care Unit in Dąbrowa Tarnowska. The method of a diagnostic poll was used in the research. A survey questionnaire regarding career and the standardised Maslach Burnout Inventory were the research tools used. The calculations were made with the use of the IBM SPSS Statistics 20 software. The adopted statistical significance was $p<0.05$.

Results: As many as $48 \%$ of the nurses felt job satisfaction. Among $41 \%$ of the nurses a high level of a burnout related with emotional exhaustion was determined, and $63 \%$ of the nurses felt a low level of burnout related to depersonalisation. Lack of the feeling of personal achievements was the cause of the high level of burnout in $62 \%$ of the surveyed. The average result of burnout scale was 50.34 points, indicating that $38 \%$ of the nurses were threatened with burnout. The age of the studied nurses, place of work (ward), and feeling the need for further education do not influence the frequency of occupational burnout occurrence.

Conclusions: Good relationships within a therapeutic team and support from the ward head nurse are strongly linked with
\end{abstract} the feeling of less occupational burnout.

\section{Streszczenie}

Wprowadzenie: Proces wypalenia zawodowego rozwija się powoli, jego początkowe objawy są bardzo dyskretne, stopniowo narastają i ujawniają się nagle z dużą siłą. Syndrom wypalenia zawodowego jest poważnym problemem indywidualnym i społecznym, którego przyczyna znajduje się w miejscu pracy lub jest związana z pracą.

Cel pracy: Ocena wypalenia zawodowego u pielęgniarek oraz ich poczucia satysfakcji z pracy zawodowej.

Materiał i metody: Badaniami objęto 100 pielęgniarek pracujących w Zakładzie Opieki Zdrowotnej w Dąbrowie Tarnowskiej. W badaniach zastosowano metodę sondażu diagnostycznego. Narzędziem badawczym była ankieta własnego autorstwa w formie kwestionariusza dotycząca pracy zawodowej oraz wystandaryzowany Kwestionariusz wypalenia zawodowego Christiny Maslach. Obliczeń dokonano za pomocą programu IBM SPSS Statistics 20. Przyjęto poziom istotności $p<0,05$. Wyniki: Satysfakcję z wykonywanej pracy odczuwało 48\% pielęgniarek. U 41\% pielęgniarek stwierdzono wysoki poziom wypalenia zawodowego związanego z wyczerpaniem emocjonalnym, 63\% pielęgniarek odczuwało niski poziom wypalenia zawodowego związanego z depersonalizacją. Brak poczucia osobistych osiągnięć był przyczyną wysokiego poziomu wypalenia zawodowego u $62 \%$ badanych. Średni wynik skali wypalenia zawodowego wyniósł 50,34 pkt, co wskazuje, że $38 \%$ pielęgniarek zagrożonych było wypaleniem zawodowym.

Wnioski: Wiek pielęgniarek, miejsce pracy (oddział) oraz odczuwanie potrzeby dalszego kształcenia się nie wpływają na częstość występowania wypalenia zawodowego. Pozytywne relacje w zespole terapeutycznym i wsparcie pielęgniarki oddziałowej istotnie zmniejszają poczucie wypalenia zawodowego.

\section{Introduction}

The problem of occupational burnout is increasingly addressed in the literature. The notion first occurred in the 1970s [1, 2]. Nowadays, the issue is dealt with not only by psychologists and sociologists, but also by researchers from other areas of medicine, pedagogy, as well as the theory of management and organisation $[3,4]$. In the course of many years' re- 
search into occupational burnout, a few definitions of this syndrome have been created. The American psychologist Freudenberger was the first to introduce the notion of "staff burnout" in 1974. He defined it as a decline in the level of an employee's energy, occurring as a result of being overwhelmed with the problems of others [2]. At present, one of the most frequently used definitions is the one created by Christina Maslach. According to her, burnout is a syndrome of emotional exhaustion, depersonalisation, and a diminished sense of personal accomplishment, which may occur among various professionals who work with other people in a specific manner [2]. The quoted definition is most often used in research into health care employees. The main professional group particularly exposed to the occurrence of burnout syndrome are health care workers, and among them nurses and doctors are the centre of the attention of this research $[3,5-7]$. The work environment is the main source of stress [8], and stress is the source of occupational burnout [4].

The process of occupational burnout develops slowly, its initial symptoms are discreet, they increase progressively, and they become manifest suddenly and with great power [3]. Burnout syndrome constitutes a serious personal and social problem [1, 3] whose cause lies in the workplace or is work related [1]. Its consequences concern the mental, emotional, physical, professional, and family sphere; thus, it is not only the worker experiencing burnout who suffers but also his or her environment [9].

A nurse is constantly involved in the patient's illness, life problems, and quite often she accompanies the patient in the dying process. It poses great emotional requirements of him/her, the consequence of which is stress [4]. Its accumulation and the lack of the ability to release it leads to chronic occupational stress, which is destructive for a nurse, bringing about lowered self-esteem and quality of work, and it affects contact with patients [4]. Many women working in the capacity of a nurse become burned out due to a lack of appreciation and recognition. Low wages generate disappointment and frustration among nurses, while responsibility in the workplace leads to burnout syndrome increasing year after year [10]. As a result, multi-dimensional burnout syndrome appears [1].

Work should be a source of happiness and a sense of fulfilment in life and a sense of job satisfaction to everyone. Satisfaction upholds the employee's readiness to work, which is why the most important goal of any actions in this area is to strive to accompany employees at all times. Burnout syndrome is a problem that we have to talk about because it is a serious threat to the employee's health. Knowledge about its existence is key to proper decisions being made by the employer to create a friendly work environment.

\section{Aim of the research}

The aims of the paper were to assess occupational burnout of nurses and the sense of satisfaction with career.

\section{Material and methods}

The method of a diagnostic poll was applied in the study. An anonymous survey questionnaire created by the author and concerning the job of a nurse and job satisfaction, as well as the standardised Maslach Burnout Inventory were the research tools. The Polish version of the Maslach Burnout Inventory (MBI) was used for the assessment of occupational burnout [11]. It is composed of 22 statements, comprising three scales: emotional exhaustion (nine items), depersonalization (five items), and personal accomplishment (eight items). Respondents answer questions about how often they feel a particular way on a $0-6$ scale, where 0 indicates "never" and 6 means "daily". Results are calculated for each of the subscales separately, according to the key. Burnout is confirmed by high results obtained on a subscale of emotional exhaustion (EE: 9-54 points) and depersonalisation (DP: 5-30 points) and low results on a personal accomplishment subscale (PA: 8-48 points). This questionnaire has been validated in Polish and achieved the following $\alpha$ values for the scales: $\mathrm{EX}=0.85$, $\mathrm{DP}=0.60, \mathrm{PA}=0.76$.

The study included 100 professionally active nurses working for the Health Care Unit in Dąbrowa Tarnowska. Having obtained the written consent of the hospital director, the survey was carried out in December 2014 and January 2015 in the following wards: Internal Medicine, Orthopaedic, Intensive Care Unit, Systemic Rehabilitation, and Neurological. The respondents participating in the research were informed about anonymity, the study objectives, and the right of refusal to participate or to withdraw consent to participate in the study at any time and without any implications. Having given their informed consent, the nurses completed the questionnaire survey unassisted.

The average age of respondents was $40.37 \pm 9.68$ years. The youngest woman was 24 years old, and the oldest was 58. The average number of years of service in the studied group of nurses was $16.83 \pm 10.54$. The number of the years of service ranged from 1 year to 38 years. The majority of nurses $(86 \%)$ worked in the two-shift system. $85 \%$ of nurses were happy with the work system in which they worked (Table 1).

\section{Statistical analysis}

The calculations were made with the use of IBM SPSS Statistics 20. The adopted level of significance was $p<0.05$. 


\section{Results}

A sense of job satisfaction prevents the occurrence of occupational burnout. A person who is satisfied works more effectively and with greater enthusiasm. The survey data analysis did not show any significant differences between sense of job satisfaction and occupational burnout in nurses, related to emotional exhaustion $(p=0.2304)$ and depersonalisation ( $p=$ 0.1106). A high sense of lack of personal accomplishment was experienced significantly more frequently ( $p=0.0211)$ by respondents who were only sometimes $(80.0 \%)$ or never $(80.0 \%)$ satisfied with the job done, in comparison with nurses who felt satisfied with their occupation (Table 2).

The job satisfaction of nurses did not significantly influence the general level of occupational burnout among them $(p=0.1429)$. Professional experience gained over the years enables nurses to assess their job satisfaction. The survey data analysis did not show any significant statistical differences between the years of service and burnout related to emotional exhaustion and depersonalisation $(p>0.05)$. No statistically significant relation was observed between the years of service and sense of job satisfaction ( $p=$ $0.5371)$. The satisfaction from the job done was slightly more often felt by nurses with the greatest number of years of service (the average 18.02 years) $-66.7 \%$. The average number of years of service of nurses who only sometimes felt job satisfaction was 15.13 (37.5\%). Nurses who more often felt job satisfaction than did not had worked in the profession for 17.76 years on average (34.8\%).

The nurses' age did not have any statistically significant influence on the general level of occupational burnout and on the occurrence of occupational burnout related to emotional exhaustion and depersonalisation $(p>0.05)$.
Table 1. The characteristics of the studied group

\begin{tabular}{|c|c|c|c|}
\hline Variables & & $N$ & $\begin{array}{c}\text { Percentage } \\
(\%)\end{array}$ \\
\hline \multirow[t]{4}{*}{ Age [years] } & $<30$ & 15 & 15 \\
\hline & $30-39$ & 33 & 33 \\
\hline & $40-49$ & 29 & 29 \\
\hline & $>50$ & 23 & 23 \\
\hline \multirow{4}{*}{$\begin{array}{l}\text { Time of } \\
\text { service [years] }\end{array}$} & $1-10$ & 40 & 40 \\
\hline & $11-20$ & 23 & 23 \\
\hline & $21-30$ & 25 & 25 \\
\hline & $31-40$ & 12 & 12 \\
\hline \multirow[t]{4}{*}{ Type of ward } & $\begin{array}{l}\text { Internal } \\
\text { medicine }\end{array}$ & 29 & 29 \\
\hline & $\begin{array}{l}\text { Systemic and } \\
\text { neurological } \\
\text { rehabilitation }\end{array}$ & 21 & 21 \\
\hline & Orthopaedic & 25 & 25 \\
\hline & $\begin{array}{c}\text { Intensive care } \\
\text { unit }\end{array}$ & 25 & 25 \\
\hline \multirow{2}{*}{$\begin{array}{l}\text { System of } \\
\text { work }\end{array}$} & 1-shift & 14 & 14 \\
\hline & 2-shift & 86 & 86 \\
\hline
\end{tabular}

Medicine is a science that is constantly developing; therefore, throughout the whole period of their professional career nurses have to educate and improve their qualifications. The survey data analysis did not show any statistically significant differences between feeling the need for further education by nurses and the occurrence of occupational burnout related to emotional exhaustion, depersonalisation, and the sense of lack of personal accomplishment $(p>0.05)$.

Table 2. Job satisfaction felt and sense of lack of personal accomplishment (PAR)

\begin{tabular}{|c|c|c|c|c|c|c|c|}
\hline \multirow[t]{2}{*}{ Variable } & & & \multicolumn{4}{|c|}{ Sense of satisfaction from job done } & \multirow[t]{2}{*}{ Total } \\
\hline & & & Yes & $\begin{array}{c}\text { Only } \\
\text { sometimes }\end{array}$ & $\begin{array}{l}\text { I more often } \\
\text { feel than do } \\
\text { not feel }\end{array}$ & No & \\
\hline \multirow{6}{*}{$\begin{array}{l}\text { Sense of lack } \\
\text { of personal } \\
\text { accomplishment } \\
\text { (PAR) }\end{array}$} & \multirow[t]{2}{*}{ Low } & $N$ & 14 & 2 & 5 & 1 & 22 \\
\hline & & $\%$ & 29.2 & 6.7 & 29.4 & 20.0 & 22.0 \\
\hline & \multirow[t]{2}{*}{ Moderate } & $N$ & 12 & 4 & 0 & 0 & 16 \\
\hline & & $\%$ & 25.0 & 13.3 & 0.0 & 0.0 & 16.0 \\
\hline & \multirow[t]{2}{*}{ High } & $N$ & 22 & 24 & 12 & 4 & 62 \\
\hline & & $\%$ & 45.8 & 80.0 & 70.6 & 80.0 & 62.0 \\
\hline \multirow[t]{2}{*}{ Total } & & $N$ & 48 & 30 & 17 & 5 & 100 \\
\hline & & $\%$ & 100.0 & 100.0 & 100.0 & 100.0 & 100.0 \\
\hline \multicolumn{3}{|c|}{ Level of significance $p$} & \multicolumn{4}{|c|}{0.0211} & \\
\hline
\end{tabular}


A nurse is a member of a therapeutic team providing broadly understood patient care. His/her job is primarily team work based on mutual respect, trust, and providing assistance to one another. Most often, a nurse cooperates with another colleague-nurse, the ward nurse, and the doctor. Nurses who could always count on help from nurse colleagues most often had a very low level of occupational burnout (18.0\%), and those who could only sometimes count on cooperation were more often affected by medium (34.2\%) or high $(15.8 \%)$ levels of occupational burnout. The differences were statistically significant $(p<0.0001)$ (Table 3 ). In other components, there was no statistically significant connection with the occurrence of the willingness to help/cooperate from a nurse colleague.

Cooperation with the doctor and the sense of respect from him/her is one of many factors influencing job satisfaction.

The sense of lack of personal accomplishment among nurses significantly depended on the occurrence of the willingness to help/cooperate from the doctor $(p=0.0116)$. Nurses who could always count on help from the doctor had a low (38.9\%) or moderate (22.2\%) level of occupational burnout in that respect. A high sense of lack of personal accomplishment was usually felt by nurses who could sometimes count on cooperation with the doctor (72.7\%). In the remaining components there was no statistically significant connection with the occurrence of the willingness to help/cooperate from the doctor.

The occurrence of occupational burnout among nurses, related to emotional exhaustion, significantly depended on the possibility to obtain help from the ward nurse ( $p=0.0207)$. A low level of occupational exhaustion in this respect was usually felt by nurses who could always count on help from the ward nurse $(51.6 \%)$, and it was more often high in nurses who could never count on such cooperation (54.4\%). The survey data analysis did not prove that occupational burnout related to depersonalisation in nurses depended in a statistically significant way on the possibility to obtain help from the ward nurse $(p=0.0766)$.

The sense of lack of personal accomplishment among nurses depended significantly on the occurrence of the willingness to help/cooperation from the ward nurse ( $p=0.0008)$. A low level of occupational burnout in that respect was presented by nurses who could always count on the ward nurse's help (45.2\%), and a high level of burnout connected with the sense of lack of personal accomplishment more frequently pertained to nurses who could only sometimes $(74.5 \%)$ or never $(77.3 \%)$ count on such help. The level of occupational burnout in nurses significantly depends on the occurrence of the willingness to help/ cooperate from the ward nurse $(p=0.0003)$. A very low level of occupational burnout occurred in nurses who could always count on help from the ward nurse (32.3\%). A low (46.8\%) and medium (38.3\%) level of occupational burnout was more frequent in persons who could sometimes count on help from the ward nurse. A high (22.7\%) and very high (13.6\%) level of occupational burnout more often concerned nurses who could never count on such cooperation (Table 4).

Wards are varied in terms of disease entity and the patient's age, and they are characterised by their own specificity of work. Depending on the workplace,

Table 3. The occupational burnout level and the occurrence of the willingness to help/cooperate from a nurse colleague

\begin{tabular}{|c|c|c|c|c|c|c|}
\hline \multirow[t]{2}{*}{ Variable } & & & \multicolumn{3}{|c|}{$\begin{array}{l}\text { Occurrence of willingness to help/ } \\
\text { cooperate from a nurse colleague }\end{array}$} & \multirow[t]{2}{*}{ Total } \\
\hline & & & Always & Sometimes & Never & \\
\hline \multirow{10}{*}{$\begin{array}{l}\text { Occupational } \\
\text { burnout level }\end{array}$} & \multirow[t]{2}{*}{ Very low } & $N$ & 11 & 2 & 0 & 13 \\
\hline & & $\%$ & 18.0 & 5.3 & 0.0 & 13.0 \\
\hline & \multirow[t]{2}{*}{ Low } & $N$ & 27 & 16 & 0 & 43 \\
\hline & & $\%$ & 44.3 & 42.1 & 0.0 & 43.0 \\
\hline & \multirow[t]{2}{*}{ Medium } & $N$ & 16 & 13 & 0 & 29 \\
\hline & & $\%$ & 26.2 & 34.2 & 0,0 & 29.0 \\
\hline & \multirow[t]{2}{*}{ High } & $N$ & 6 & 6 & 0 & 12 \\
\hline & & $\%$ & 9.8 & 15.8 & 0.0 & 12.0 \\
\hline & \multirow[t]{2}{*}{ Very high } & $N$ & 1 & 1 & 1 & 3 \\
\hline & & $\%$ & 1.6 & 2.6 & 100.0 & 3.0 \\
\hline \multirow{2}{*}{\multicolumn{2}{|c|}{ Total }} & $N$ & 61 & 38 & 1 & 100 \\
\hline & & $\%$ & 100.0 & 100.0 & 100.0 & 100.0 \\
\hline \multicolumn{3}{|c|}{ Level of significance $p$} & & $<0.0001$ & & \\
\hline
\end{tabular}


Table 4. The level of occupational burnout and the occurrence of the willingness to help/cooperate from the ward nurse

\begin{tabular}{|c|c|c|c|c|c|c|}
\hline \multirow[t]{2}{*}{ Variable } & & & \multicolumn{3}{|c|}{$\begin{array}{l}\text { Occurrence of willingness to help/ } \\
\text { cooperate from the ward nurse }\end{array}$} & \multirow[t]{2}{*}{ Total } \\
\hline & & & Always & Sometimes & Never & \\
\hline \multirow{10}{*}{$\begin{array}{l}\text { Level of } \\
\text { occupational } \\
\text { burnout }\end{array}$} & \multirow[t]{2}{*}{ Very low } & $N$ & 10 & 2 & 1 & 13 \\
\hline & & $\%$ & 32.3 & 4.3 & 4.5 & 13.0 \\
\hline & \multirow[t]{2}{*}{ Low } & $N$ & 12 & 22 & 9 & 43 \\
\hline & & $\%$ & 38.7 & 46.8 & 40.9 & 43.0 \\
\hline & \multirow[t]{2}{*}{ Medium } & $N$ & 7 & 18 & 4 & 29 \\
\hline & & $\%$ & 22.6 & 38.3 & 18.2 & 29.0 \\
\hline & \multirow[t]{2}{*}{ High } & $N$ & 2 & 5 & 5 & 12 \\
\hline & & $\%$ & 6.5 & 10.6 & 22.7 & 12.0 \\
\hline & \multirow[t]{2}{*}{ Very high } & $N$ & 0 & 0 & 3 & 3 \\
\hline & & $\%$ & 0.0 & 0.0 & 13.6 & 3.0 \\
\hline \multirow{2}{*}{\multicolumn{2}{|c|}{ Total }} & $N$ & $N$ & 47 & 22 & 100 \\
\hline & & $\%$ & $\%$ & 100.0 & 100.0 & 100.0 \\
\hline \multicolumn{3}{|c|}{ Level of significance $p$} & & 0.0003 & & \\
\hline
\end{tabular}

nurses, with various intensity, encounter patient's problems, suffering, disability, and death. The study proved the lack of a significant relationship between the ward type and individual components of occupational burnout.

The study showed that the workplace properly equipped with medical devices significantly influenced the sense of contentment with the organisation of work among the respondents $(p=0.0002)$. Job satisfaction was significantly more often felt by nurses who claimed that the workplace was always equipped with medical devices (36.4\%). Nurses discontented with the organisation of work more often claimed that their workplace was not equipped with adequate medical equipment (32.1\%).

\section{Discussion}

Occupational burnout is a very common phenomenon among numerous professions worldwide. More and more people experience exhaustion of work; therefore, the subject [6] arouses a need for constant diagnosis of causes, results, and prevention of this phenomenon. The main professional group included in the research into the burnout syndrome are nurses. Due to constant contact with people expecting emotional support and help, the profession evokes a specific kind of occupational stress affecting all spheres of life, which is the reason why nursing staff belongs to the group with the highest level of the risk of the occurrence of occupational burnout [6]. Its symptoms are insidious, often explained as temporary fatigue or "a bad day at work", and in fact they develop slowly, sometimes even for years, and lead to serious conse- quences in professional and private life. Mastalerz thinks that a professional career is both a source of satisfaction and stress, the effect of which may be the development of burnout [12].

From our own research it has not been proven that the sense of job satisfaction of nurses is significantly related to the general level of occupational burnout among them. A similar relationship was identified in the research conducted by Sowińska et al. [13]. In her publication, Andruszkiewicz expresses her concern caused by the growing lack of satisfaction (discontentment) of nurses from the job done, which in the future may be a serious source of crisis because it adversely affects the development of the profession [14]. It has been confirmed for years in the observed strikes and protests of nurses.

As a result of our own research, no significant influence of the years of service of nurses on the general level of occupational burnout was discovered; however, it influences individual dimensions of burnout, including the sense of lack of personal accomplishment. High results were more often achieved by nurses with 1-10 years of service $(80.0 \%)$, which is reflected in the research conducted by Nowakowska and Rasińska [15]. In respondents with the shortest period of work experience the symptoms of developing occupational burnout were greatest. This happens because responsibility for another person's health and life brings about much greater difficulties to people who are just commencing their job. It may potentially be influenced by the lack of accumulation of personal problems, the sense of the freshness of knowledge, or not experiencing the significance of this type of re- 
sponsibility [16]. The lack of a statistically significant relationship between the years of service and burnout was also obtained in the research carried out by Lewandowska and Litwin [9], in a research of bridging part-time undergraduate studies at the Medical University of Gdansk [13], and in a study of nurses from Kuyavian-Pomerenian Voivodeship [17]. The last study proved that the number of years of service influences only the elements of the personality sphere, such as: professional ambitions and offensive problem solving [17]. Other studies have proven that the greater the number of the years of service, the more often occupational burnout occurs $[6,18]$. The contradictions present in the available literature on the subject mean the relationship continues to be an open problem [13].

When analysing the relationship between the age of the surveyed nurses and occupational burnout, our own research did not reveal any significant influence of age on the general level of occupational burnout. Similar results were presented by Tarcan et al. [19], and contrasting ones by Zhu et al. It can be concluded from their research that with age workers' occupational burnout increases [20]. Statistically significant differences occurred between the age and occupational burnout in nurses, related to the sense of lack of personal accomplishment, which was more often presented by younger nurses. Similar results were presented by the research conducted by Lewandowska and Litwin [9].

The job of a nurse requires constant improvement of qualifications, which is related to an increase in the sense of professionalism and competence [7]. Qualification improvement positively influences the self-assessment of a nurse, it extends his/her scope of competences, can lead to promotion, and increases the prestige of the job. It is also a way to prevent the occurrence of occupational burnout [7, 21]. In our own research, more than a half of the respondents expressed a need/willingness to further their education; however, it did not correlate with the occurrence of occupational burnout. The research of Karakoc et al. indicate that continuous education is important, particularly for younger nurses, because it will minimise the risk of occupational burnout in their further career [22].

In the job of a nurse, mutual cooperation in the therapeutic team is very important. The sense of support from a nurse colleague, the ward nurse, and the doctor influences the sense of satisfaction from the job and prevents occupational burnout [13]. As a result of our own research, it was discovered that the assessment of the atmosphere in the ward significantly depended on cooperation with a nurse colleague, the doctor, and the ward nurse. The results obtained in the research are comparable with others available in the literature. In the research carried out by Sowińska et al., the majority of respondents said that a nervous atmosphere among the therapeutic team affects their satisfaction with the job done [13]. An analysis of the research conducted by Dłużewska, Poncet, et al. enables us to draw the conclusion that conflicts among colleagues positively correlate with all three dimensions of burnout [16, 23].

When analysing the relationship between the nurses' place of work and the occurrence of burnout, in our own research it was not shown that the general level of occupational burnout among nurses depends on the ward in which they work. Different results are presented by the research carried out by Nowakowska and Rasińska, in which significant relationships between the type of ward and occupational burnout in all three dimensions were proven [15]. Likewise, the research by Wyderka et al. [3], as well as by Ríos-Risquez and García-Izquierdo [24], showed an impact of the workplace on the intensity level of the occurrence of burnout symptoms in the dimension of emotional exhaustion and the lack of personal accomplishment.

Proper conditions for patient treatment and care, including adequate furnishing of work stations with medical equipment, are one of the more important elements influencing the sense of job satisfaction. In our own research job satisfaction was significantly more often felt by nurses who claimed that the workplace was always equipped with medical devices (36.4\%). This was confirmed in the research carried out by Głowacka and Nowakowska [25]. In the research by Sowińska et al., respondents also thought that the equipment in the workplace was satisfactory [13]. Those research findings are consistent with the opinion that the supply in medical devices influences job satisfaction.

Professional burnout is an individual and social problem [3]; therefore, its consequences affect a person experiencing this phenomenon, as well as the environment in which he or she lives. Its essence is mental erosion which takes place in a person in terms of the sense of self-esteem, personal dignity, and will. It leads to numerous disorders in psychological, social, and physiological functioning of an individual [12] as well as resignation from their current job [26]. The main cause of occupational burnout is stress formed in the workplace which a given person cannot handle, persisting for a longer time; therefore, occupational burnout prevention is closely linked to stress prevention $[27,28]$.

\section{Conclusions}

The sense of the lack of personal accomplishment among nurses, being one of the elements of occupational burnout, is impacted by sense of satisfaction with career and length of work experience. The age of studied nurses, place of work (ward), and feeling the need for further education do not influence the frequency of occupational burnout occurrence. 
Lack of appropriate number of staff and amount of medical equipment generate dissatisfaction of nurses with wok organisation. Good relationships within a therapeutic team, cooperation with colleagues and doctors, and support from the ward head nurse are strongly linked with the feeling of less occupational burnout.

\section{Conflict of interest}

The authors declare no conflict of interest.

\section{References}

1. Ptaszek G, Sołecka B, Graf L, Śleziona M. Wypalenie zawodowe pielęgniarek. Pielęg Specjal 2014; 1: 180-184.

2. Tucholska S. Christiny Maslach koncepcja wypalenia zawodowego: etapy rozwoju. Przegl Psychol 2001; 44: 301-317.

3. Wyderka M, Kowalska H, Szelag E. Wypalenie zawodowe jako problem występujący wśród pielęgniarek. Pielęg Pol 2009; 4: 265-275.

4. Dawidziuk K, Lishchynskyy Y, Wojciechowska M, Kopański Z, Marczewska S, Uracz IN. Stres jako źródło wypalenia zawodowego. J Public Health Nursing Medical Rescue 2011; 4: 26-29.

5. Jachimowicz-Wołoszynek D, Jakubowska M, Leźnicka M. Analiza zachowań i przeżyć związanych z pracą na przykładzie pielęgniarek. Probl Hig Epidemiol 2011; 92: 725 732 .

6. Kędra E, Sanak K. Stres i wypalenie zawodowe w pracy pielęgniarek. Pielęg Zdrowie Publ 2013; 3: 119-132.

7. Kowalczuk K, Zdańska A, Krajewska-Kułak E, Łukaszuk C, Van Damme-Ostapowicz K, Klimaszewska K, Kondzior D, Kowalewska B, Rozwadowska E. Stres w pracy pielęgniarek jako czynnik ryzyka wypalenia zawodowego. Probl Pielęg 2011; 19: 307-314.

8. Sęk H. Poznawcze i kompetencyjne uwarunkowania wypalenia w pracy z chorymi. Postep Psych Neurol 2005; 14: 93-98.

9. Lewandowska A, Litwin B. Wypalenie zawodowe jako zagrożenie $\mathrm{w}$ pracy pielęgniarki. Rocz Pom Akad Med Szczecin 2009; 55: 86-89.

10. Sapilak BJ. Wypalenie zawodowe personelu medycznego. [In:] Stres oraz wypalenie zawodowe. Steciwko A, Mastalerz-Migas A (eds.). Elsevier Urban \& Partner, Wroclaw 2012.

11. Pasikowski T. Polish adaptation of the Maslach Burnout Inventory. In: Job Burnout: Causes and Prevention. Sęk H. PWN, Warsaw 2012.

12. Mastalerz M. Zaburzenie po stresie traumatycznym (PTSD). Remedium. Profilaktyka i promocja zdrowego stylu życia. Remedium 2010; 1: 22-23.

13. Sowińska K, Kretowicz K, Gaworska-Krzemińska A, Świetlik D. Wypalenie zawodowe i satysfakcja zawodowa w opinii pielegniarek. Probl Pieleg 2012; 20: 361-368.

14. Andruszkiewicz A. Typy zachowań i przeżyć w pracy w grupie pielęgniarek. Probl Pielęg 2007; 15: 159-161.

15. Nowakowska I, Rasińska R. Związek wybranych czynników socjodemograficznych z wypaleniem zawodowym wśród pielęgniarek. Pielęg Pol 2014; 1: 26-33.

16. Dłużewska M. Eksploracja uwarunkowań w powstawaniu procesu wypalenia zawodowego - analiza na podstawie badań własnych. Pielęg Pol 2012; 2: 63-72.
17. Sygit E. Długoletni staż zawodowy pielęgniarek - droga ku wypaleniu zawodowemu? Rocz Pom Akad Med Szczecin 2009; 55: 83-89.

18. Dębska G, Cepuch G. Wypalenie zawodowe u pielęgniarek pracujących w zakładach podstawowej opieki zdrowotnej. Probl Pielęg 2008; 16: 273-279.

19. Tarcan M, Hikmet N, Schooley B, Top M, Tarcan GY. An analysis of the relationship between burnout, socio-demographic and workplace factors and job satisfaction among emergency department health professionals. Appl Nurs Res 2017; 34: 40-47.

20. Zhu T, Zhang SS, Chen DY, Yang H, Zheng T, Zheng LM, $\mathrm{Li} \mathrm{J}$. Job burnout and related influencing factors in community medical staff in Nanchong, China. Zhonghua Lao Dong Wei Sheng Zhi Ye Bing Za Zhi 2016; 34: 928-930.

21. Lahana E, Papadopoulou K, Roumeliotou O, Tsounis A, Sarafis P, Niakas D2. Burnout among nurses working in social welfare centers for the disabled. BMC Nurs 2017; 16: 15.

22. Karakoc A, Yilmaz M, Alcalar N, Esen B, Kayabasi H, Sit D. Burnout syndrome among hemodialysis and peritoneal dialysis nurses. Iran J Kidney Dis 2016; 10: 395-404.

23. Poncet MC, Toullic P, Papazian L, Kentish Barnes-N, Timsit JF, Głowienka F, Chevret S, Schlemmer B, Azoulay E. Burnout syndrome in critical care nursing staff. Am J Respir Crit Care Med 2007; 175: 698-704.

24. Ríos-Risquez MI, García-Izquierdo M. Patient satisfaction, stress and burnout in nursing personnel in emergency departments: a cross-sectional study. Int J Nurs Stud 2016; 59: 60-67.

25. Głowacka MD, Nowakowska I. Wypalenie zawodowe pielęgniarek a funkcjonowanie zawodowe wobec pacjenta. [In:] Zarządzanie zakładem opieki zdrowotnej. Konteksty i determinanty zmian. Głowacka MD (scientific editor). Wydawnictwo Polskie Towarzystwo Nauk o Zdrowiu, Poznań 2011; 173-186.

26. Radkiewicz P, Widerszal-Bazyl M, Pokorski J, Pokorska J, Ogińska H, Pietsch E. Dlaczego pielęgniarki wcześnie odchodzą z zawodu? Bezpieczeństwo Pracy 2004; 7-8: 31-34.

27. Dębska G, Pasek M, Wilczek-Rużyczka E. Obciążenia psychiczne i wypalenie zawodowe $u$ pielęgniarek pracujących w różnych specjalnościach zawodowych. Hygeia Public Health 2014; 49: 113-119.

28. Wilczek-Rużyczka E, Zaczyk I. Wypalenie zawodowe polskich pielęgniarek - metaanaliza badań. Hygeia Public Health 2015; 50: 9-13.

\section{Address for correspondence:}

\section{Aneta Grochowska}

Department of Nursing Institute of Health Protection

The State Higher Vocational School

ul. Mickiewicza 8, 33-100 Tarnów, Poland

Phone: +48692802566

E-mail: apea1@op.pl 